\title{
Making the right move
}

A successful career is often not limited to a steady progression through the ranks. In the first of our career snapshots, two industry leaders highlight some of the factors that were important for them when making major career moves.

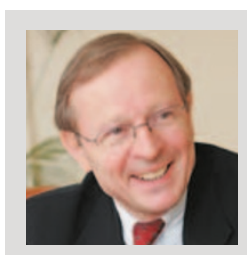

\begin{abstract}
Jean Deregnaucourt, Presidential Advisor, Pierre Fabre Laboratories, Paris
2003-2005 Director of Biotechnologies, French Research Ministry, Paris

1998-2003 President of the Research Institute of Pierre Fabre, and Director of Research and Development, Pierre Fabre Drug Laboratories, Paris

1994-1998 Vice President, Chemical and Pharmaceutical Development, Rhône-Poulenc Rorer
\end{abstract}

After 3 years as Director of Biotechnologies at the French Research Ministry, where he was responsible for projects such as fostering public-private collaborations and the French contribution to the EU Seventh Research Framework Programme, Jean Deregnaucourt has returned to industry, and to the company he previously worked for. So, why did he leave a highly regarded senior government position to renew his ties with Pierre Fabre?

"Above all, I wanted to return to working closely with a fantastic entrepreneur, Pierre Fabre," says Deregnaucourt. "He created and made successful an innovative company while maintaining a strong ethical emphasis. It's very motivating to learn from an outstanding boss." Experiencing the stimulation of a competitive environment, and the reward of working to improve human health, were also attractions. And last but not least, he felt confident that the experience gained in his governmental position would be valuable.

When he was given the chance to take this ministerial position in 2003, Deregnaucourt had been RED President at Pierre Fabre for 4 years, managing $\sim 800$ people developing drugs for cancer and immunological, cardiovascular and central nervous system diseases. "In my view, a career move every $3-5$ years is good both for the organization, which can benefit from a new head bringing in new ideas and energy, and for the mover, who can be stimulated by the new challenge," he says. "So, when the opportunity at the ministry arose, I was open to the idea, and attracted by the potential to make an impact on my country's research environment. I was aware that there was some risk with regard to the possibility

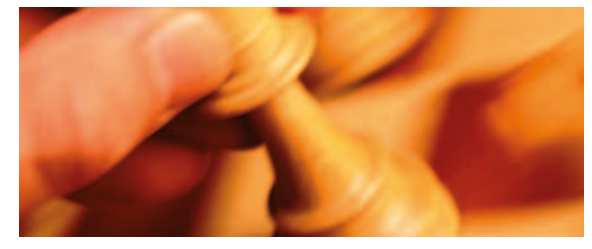

of a subsequent move back to industry, but my enthusiasm for the new position outweighed this."

During his time at the ministry, Deregnaucourt and colleagues promoted a series of initiatives including the establishment of a European network of innovations in biotechnology, and worked on a law intended to revitalize French research that was recently proposed to the French parliament. After these rewarding experiences, Deregnaucourt felt a chapter was over. "I was ready for a new move, with a wealth of new knowledge," he explains. "I had two possibilities - to head up a new French biocluster or to return to Pierre Fabre - and I chose the latter".

\section{Box 1 | Tips for a productive move}

- The timing must be appropriate: $3-5$ years in each position is usually needed to deliver and make the most of opportunities to learn.

- Aim to enlarge or deepen the field of your expertise; this will allow you to become more efficient and employable.

- The quality of the new boss should be a key criterion.

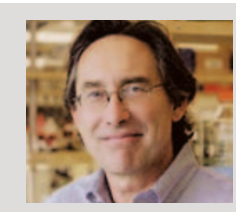

Alan Lewis, President and CEO, Novocell, Irvine, California

2000-2006

1994-2000

President, Signal Research, Celgene, San Diego

1989-1994

President and CEO, Signal Pharmaceuticals, San Diego

Vice President, Discovery Research, Wyeth, Princeton

As President of the drug discovery wing of Celgene, one of the world's ten largest biotech companies, the resources available to Alan Lewis to catalyse new research would have been the envy of many fledgling biotechs. But in 2006,

Lewis made the decision to leave Celgene to lead just such a biotech - Novocell — with the aim of developing cell-based therapies for diabetes and other degenerative diseases.

\section{Box 2 | Tips for a productive move}

- Treat your career as a journey with opportunities to grow both professionally and personally.

- Take full advantage of chances to change career path and 'reinvent' yourself periodically, and embrace change.

- Experience start-ups as well as more mature companies to benefit from the different cultures and challenges they provide.
"I missed the excitement of the early-stage biotech company," explains Lewis. "I had watched with great interest the debate around stem-cell research in California, and was attracted by the revolutionary potential of regenerative medicine. So I was excited to be given the opportunity to join Novocell."

This was not the first time that Lewis had made such a career jump. After moving up the ranks at Wyeth to head their research site in Princeton, he became intrigued by the biotech industry, and started to investigate partnership opportunities. "The biotech companies I met with were doing cutting-edge biomedical research. They also seemed less bureaucratic and more nimble than typical pharma companies, and so I decided to explore the possibility of joining one," Lewis says.

But what about the risk? "It helps to be moving to a location with both a strong academic and biotech base so that other opportunities will be available if things don't work out," notes
Lewis. "But moving to a biotech company with limited resources takes courage. And you should carefully consider the strength of the intellectual property base and the long-term willingness of the investors." Signal Pharmaceuticals, the company he joined, was venture-backed, with a few postdoctoral fellows and a skeleton staff. "It was a shock after being responsible for 500 staff. My first job was to raise money without which we could not survive," recalls Lewis. "Given this, it was important to quickly become passionate about the projects within the company." Signal blossomed, and was ultimately acquired by Celgene in 2000.

Building things from scratch is clearly one common thread in Lewis's career, and these experiences should help at Novocell, where again raising money will be a key task. "Gaining FDA support for first-in-class products and dealing with the complex political and ethical issues surrounding stem-cell therapies are also going to be crucial," says Lewis.

This desire to develop innovative therapies is a second common thread for Lewis. When he originally entered industry at Organon in the UK, he was convinced that it would just be for a few years before returning to academia. "But I thoroughly enjoyed the concept of 'drug hunting," say Lewis, "and I have been involved in this in some way ever since." 